\title{
Flowering levels, harvest season and yields of cupuassu (Theobroma grandiflorum) ${ }^{1}$
}

\author{
Giorgini Augusto VENTURIERI ${ }^{1}$
}

\begin{abstract}
Cupuassu (Theobroma grandiflorum), a specie native to Amazonia, has been planted commercially in Brazil to satisfy the demand for the flavorful juice obtained from the pulp around its seeds. The trees are notorious for low and irregular fruit production. Data gathered over two seasons from trees in a germplasm collection in Pará, Brazil, showed that some of them fruited more regularly than others. Differences in fruit production correlated to differences in flower production. Tree-to-tree variation in flower production, fruit production, and consistency of both over time suggest considerable scope for improving yields by selection. Hand pollinations resulted in a much higher frequency of fruit set than open pollinations, indicating that lack of effective pollination is also a reason for low yield. However, attempts to increase the level of effective pollination are handicapped by low knowledge about the pollinators of cupuassu and their behavior.
\end{abstract}

KEYWORDS: effective pollinator, flower production, fruit set, irregular bearing

\section{Níveis de floração, período de safra e produção do cupuaçuzeiro (Theobroma grandiflorum)}

\begin{abstract}
RESUMO
Cupuaçu (Theobroma grandiflorum) é uma espécie nativa da Amazônia que vem sendo plantada comercialmente no Brasil para satisfazer a demanda pelo seu suco, de sabor marcante, obtido da polpa que envolve as suas sementes. As árvores não notórias pela sua baixa e irregular produtividade. Dados obtidos de dois períodos produtivos, de árvores de uma coleçáo de germoplasma no estado do Pará, Brasil, mostraram que algumas delas frutificam mais irregularmente que outras. Diferenças na produção de frutos foram correlacionadas à diferenças na produção de flores. Variaçóes entre plantas nas produçóes de flores e de frutos, e a repetibilidade de ambos ao longo do tempo sugerem melhoria das colheitas por seleção. Polinizaçóes manuais resultaram em aumento no pegamento dos frutos, indicando que a falta de polinizador efetivo é também um causa da produtividade baixa. Entretanto, tentativas para aumentar o nível de polinizaçáo efetiva são dificultadas pelo pouco conhecimento sobre os agentes polinizadores do cupuaçu e seu comportamento.
\end{abstract}

PALAVRAS-CHAVE: polinizador efetivo, produçáo de flores, pegamento dos frutos, colheitas irregulares. 


\section{INTRODUCTION}

Cupuassu (Theobroma grandiflorum (Willd. ex Sprengel) Schumann, family Sterculiaceae) is a native of eastern Amazonia. Wild trees occur in the underst orey of the forests of eastern Pará and western Maranhão in Brazil. Cupuassu is planted and protected by various indigenous groups and is cultivated in house gardens as far west as Peru and Colombia by non-indigenous settlers (Smith et al. 1992). As in its better-known relative, the cacao (T. cacao L.), the seeds are rich in fat and are surrounded by a juicy pulp, but the fat of cupuassu seeds has a lower melting point than that of cacao (Silva 1988), so cupuassu is not generally used in chocolate manufacture. However, the characteristic acid-sweet flavor of the pulp has proved widely acceptable both within Brazil and internationally and cupuassu is expanding rapidly into the world market for exotic fruit flavors for use in juices and ice-creams (Clement and Venturieri 1990). By the 1980s demand exceeded supply and cupuassu was one of the most expensive local fruits in Amazonia. A single fruit would sell for up to US $\$ 2.00$, and a tonne of frozen pulp fetched US $\$ 4,000$ (Venturieri 1993). This has resulted in a great increase in cupuassu plantations. Cupuassu is also often recommended as a cash crop for multi-crop integrated agroforestry systems, in part because it is potentially so profitable and in part because, as a member of the forest understorey, it is tolerant of shade (Moraes et al. 1994; Smith et al. 1992; Venturieri 1993).

The fruits of cupuassu are the largest known in Theobroma. They weigh 200-4,000 g and contain 30-50 seeds, which account for $17 \%$ of the fruit weight. Relatively few flowers develop into fruits. Yields are low compared to those of other fruit trees and yields per tree are extremely variable (Venturieri 1993). The reasons for this have not yet been established, but may relate to inadequate pollination, inadequate supply of nutrients, or both. Like other species of Theobroma, cupuassu has structurally complex flowers. A biotic vector of some kind is required to convey pollen from the petal pouches, into which it is shed, to the stigmas. Most trees are self-incompatible (Venturieri 1994), so the pollinator must move between trees to bring about effective pollination, though there are some reports of isolated trees which produce fruit, presumably by self-pollination (Venturieri 1993). Venturieri (1994) found that fewer than $2 \%$ of naturally-pollinated cupuassu flowers had over 50 pollen grains on their stigmas. This is low even for Theobroma, in which only $2-4 \%$ of flowers are recorded as being effectively pollinated in T. cacao (Free 1993; Parvais et al. 1977), $7.5 \%$ in T. obovatum Klotzsch ex Bernouilli (Souza and Venturieri 1998), 18.7\% in T. subincanum Mart. (Rodrigues and Venturieri 1997) and 20\% in T. speciosum Willd. ex Sprengel (Souza and Venturieri, 2010). Selecting for more flowers per tree might increase yield by increasing the attractiveness of the tree to the pollinator (Faegri and van der Pijl 1979). Changes in the length of the flowering season, particularly insofar as these increase or decrease competition with other plant species which use the same pollinators, or extend the period during which particular pollinators can remain active within the plant community as a whole, might also affect the proportion of flowers which are effectively pollinated and hence affect yield. Pollen vectors are very difficult to identify in Theobroma, but in cupuassu the most likely candidates are chrysomelid weevils (Venturieri et al. 1997) and stingless bees (Venturieri 1994). Small pollinators such as these may not fly freely during periods of heavy rain, so weather during the flowering season may also influence yield.

Species with fruits which are energetically expensive to produce, such as cacao or avocado (Persea americana L.), often mature relatively few fruits compared to the numbers of flowers produced because the mother tree is physiologically incapable of filling all the fruits which set. In this case, fruits are aborted after pollination, not because of a failure of pollination (Stephenson 1981), and improving the nutrient status of the trees may increase the number of fruits which mature successfully.

Commercial production of cupuassu requires the fruits to be processed to extract the juice from the pulp before the pulp ferments, and the extracted juice then has to be frozen or pasteurized. Processing plants depend on a predictable and even workload throughout the year to keep the machinery and labor force operating at optimum capacity. It is important to be able to forecast cupuassu yields as early as possible each season for this reason and also so that growers may warn of possible problems in fulfilling contracts.

Little information is available on variation within cupuassu with respect to flowering period, rate at which fruits mature, relation between number of flowers produced and yield of fruit, effects of weather conditions at or after pollination, regularity of bearing, and response to irrigation or artificial fertilizers. This information is needed in order to assess whether selection for these features is likely to be an effective strategy for improvement of cupuassu, either as a plantation crop or as a cash crop for cooperatives of small-scale farmers cultivating without totally clearing the rain forest. This study provides preliminary data on some of these points.

\section{MATERIALS AND METHODS}

\section{Study population}

The trees used in this study included 20 from the Basil Bartley living collection of species of Theobroma and 94 from a sub-spontaneous population of mature cupuassu trees. The trees were maintained at the "José Haroldo" Experimental Station for Cocoa Genetic Resources, of the Executive Commission for Cocoa Crop Planning (CEPLAC), in the 
municipality of Marituba, Pará, Brazil ( $1^{\circ} 12^{\prime} \mathrm{S}$; $\left.49^{\circ} 13^{\prime} \mathrm{W}\right)$. The trees in the Basil Bartley collection were planted in 1984 from seeds of three different fruits, collected in different parts of Amazonia. Their identifying numbers are preceded by the letter $\mathrm{F}$. The origin of the sub-spontaneous trees is not recorded, but they are thought to derive from trees planted by the caboclos (peasant farmers) who originally owned the land on which the Experimental Station now stands. Their ages have been roughly estimated from the sizes of their trunks as ranging from ten to 85 years (Venturieri 1994).

All trees were cultivated on the type of oxisol common in the uplands of the state of Pará, with limited drainage and low fertility. For three years prior to the start of this study, trees in the Basil Bartley collection had been treated annually with $0.15 \mathrm{~kg}$ of artificial fertilizer (NPK 10-30-20 formulated using ingredients produced by Ultrafertil S/A - Cataláo - GO), while the sub-spontaneous trees were not treated. In December 1991, seven of the study trees (three subspontaneous trees and four trees in the Basil Bartley collection) received a mixture of equal parts of artificial fertilizer and Yoorin MG (produced by Fertilizantes Mitsui S/A- Poços de Caldas - MG, containing $\mathrm{P}_{2} \mathrm{O}_{5} 18 \%, \mathrm{Mg} 14.5 \%$; $\mathrm{CaO} 28 \%$, and traces of $\mathrm{Zn}, \mathrm{Bo}, \mathrm{Si}$, $\mathrm{Fe}, \mathrm{Mn}, \mathrm{Co}$ and $\mathrm{Cu}$ ). The trees in the Basil Bartley collection received $0.3 \mathrm{~kg}$ of this mixture, the older sub-spontaneous trees received $1 \mathrm{~kg}$. The subspontaneous trees received more fertilizer because the trees were bigger.

The monthly rainfall data during the period of the study were available from the records made by the Experimental Station.

\section{Length of flowering season and number of flowers produced}

Observations were made from June to December 1991 and from May 1992 to January 1993. The number of flowering trees was recorded each 15 days and the trees were classified on the basis of the number of open flowers per tree: zero $=$ no open flowers; one $=$ up to ten open flowers; two $=11-50$ open flowers and three $=$ more than 50 open flowers. The length of the flowering season for each tree was considered as the time it bore any flowers.

The number of flowers produced per tree was calculated from the number of 15-day periods the tree spent in each of the three classes before mentioned, multiplied by the mean number of flowers for that class (considered as 70 flowers for class three). Since each flower lasts only one day, each class figure so obtained was multiplied by 15 , and the totals for the three classes then summed as an estimate of the total number of flowers produced by each tree.

\section{Fruit production, time to maturity and length of harvest season}

The numbers of fruits produced by open pollination in 1991/92 and 1992/93 (hereafter referred to as first and second season, respectively) were counted on each tree on December 30th 1991 and 1992, after they had passed the critical period for fruit drop but before they were fully mature

During the second season, some flowers on eight trees were hand pollinated, as described by Venturieri and Ribeiro Filho (1995). The time to fruit maturity, i.e. number of days from pollination to fruit fall, was calculated for these fruits because their dates of pollination were known with certainty. The fruits were enclosed in net-bags and checked for fallen fruit each 15 days during both seasons in order to assess the length of the fruiting season.

\section{Statiscal analyses}

Correlations among days from pollination and weight of fruit, length and intensity of flowering, total number of flowers and total number of fruits per tree in each season were assessed by Pearson's correlation coefficient (Sokal and Rohlf, 1995). Number of days from pollination to fruit ripening were statistically compared using $t$ test (Sokal and Rohlf, 1995).

\section{RESULTS}

\section{Phenology of flowering}

Comparison of monthly rainfall (Figure 1) with the percentage of trees flowering each month (Figure 2) shows that, in both first and the second season, peak flowering occurred during the driest period of the year (July-September in 1991; October-December in 1992). The fact that maximum flowering in this population can vary by as much as three months suggests that flowering is not controlled by daylength, which in any case varies very little at the latitude of this study. Water supply for the trees is never limiting since there is never a soil water deficit (Garcia et al. 1985). Light intensity is markedly lower during the rainy season because of cloud cover, and light intensity may be the major factor controlling initiation of flowers in cupuassu, as has been suggested for Hevea brasiliensis, another amazonian species, that flowering months generally coincide with the months of the highest average solar irradiation measured at the ground not in the upper atmosphere (Hoong-Yeet 2007).

In the first season, $68 \%$ of the trees flowered simultaneously in the second half of August, and in the second season, 55\% of the trees flowered simultaneously in the second half of November (Figure 2). Over half of the trees in this population were therefore potentially able to inter-pollinate. 


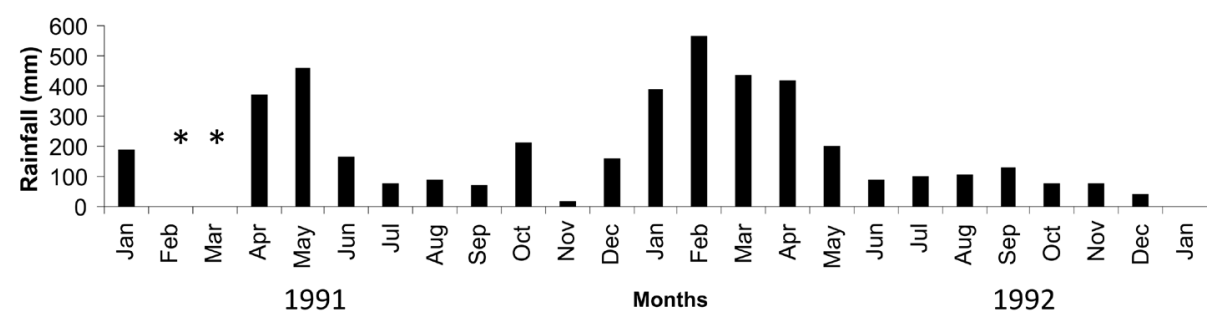

Figure 1 - Monthly rainfall at the Experimental Station for Cocoa Genetic Resources "José Haroldo"(ERJOH), Marituba, Pará, Brazil during the period of study $\left({ }^{*}=\right.$ data not available).

In the first season, ten $(8.8 \%)$ of the trees studied never flowered, while in the second season 31(27.6\%) failed to flower. Eight (7.14\%) trees did not flower in either season. Some trees flowered very sparsely, and for a limited period only (e.g. tree 200-26, Figure 3a). Other trees flowered abundantly, either in both seasons (e.g. trees 229-25 and F13-2, Figure $3 \mathrm{~b}$ ) or in one season only (e.g. tree 513-23 in the first season, Figure $3 \mathrm{~b}$ ). Trees that flowered abundantly produced most of their flowers in a short period of peak flowering (class 3 ), usually preceded and followed by periods of less intense flowering (class 1 or class 2).

\section{Phenology of fruiting}

In the first season 178 ripe fruits were produced from open pollination, but only $48 \%$ (50 out of 104) of the trees which flowered in that season. Mean number of fruits per tree, considering only the fruiting trees, was 6.6. In the second season, 162 fruits were produced by $44 \%$ (35 out of 79) of the trees which flowered, with a mean of 4.5 fruits per fruiting tree. Only 55 out of over 100 trees studied produced any fruit during the period of these observations.

The numbers of fruits set on the most productive and least productive trees in each season are shown in Table 1 This clearly illustrates the great variation in yield between different trees in the same season (from 0 to 28 fruits per tree) and the same tree in different seasons (from eight to 28 fruits). The data suggest that a tree which fruits heavily in one season (e.g. trees 513-23 and 492-28) may set relatively few fruit in the following season, but unfortunately the observations could not be continued for long enough to establish whether there is really a tendency to biennial or irregular bearing in this species.

The percentage of flowers which set fruit following hand pollination was much greater than the percentage which set fruit following natural pollination $(10 \%$ versus less than $0.5 \%)$. This suggests that effective pollination may be the

Table 1 - Fruit production in consecutive seasons on some individual trees of cupuassu (figures in parentheses = fruits set by hand pollination; * tree treated with $0.3 \mathrm{~kg}$ fertilizer, ${ }^{* *}$ tree treated with $1.0 \mathrm{~kg}$ fertilizer).

\begin{tabular}{|c|c|c|c|c|c|c|c|c|c|}
\hline \multirow{2}{*}{\multicolumn{5}{|c|}{$\begin{array}{l}\text { Most productive trees } \\
\text { Number of fruits set }\end{array}$}} & \multirow{2}{*}{\multicolumn{4}{|c|}{$\begin{array}{l}\text { Least productive trees } \\
\text { Number of fruits set }\end{array}$}} & \multirow[t]{3}{*}{ Mean } \\
\hline & & & & & & & & & \\
\hline Tree & First season & Second season & Total & Mean & Tree & First season & Second season & Total & \\
\hline $229-25^{* *}$ & 1 & $36(22)$ & 37 & 18.5 & $200-26$ & 1 & 0 & 1 & 0.5 \\
\hline $492-60$ ** & 6 & $31(6)$ & 37 & 18.5 & $216-23$ & 0 & 1 & 1 & 0.5 \\
\hline 513-23 & 28 & 8 & 36 & 18 & $223-34$ & 1 & 0 & 1 & 0.5 \\
\hline $492-28$ & 26 & 4 & 30 & 15 & $288-22$ & 0 & 1 & 1 & 0.5 \\
\hline $283-56$ & 7 & $23(19)$ & 30 & 15 & $298-19$ & 1 & 0 & 1 & 0.5 \\
\hline $545-33$ & 8 & 21 & 29 & 14.5 & $302-36$ & 1 & 0 & 1 & 0.5 \\
\hline 534-33 & 19 & 10 & 29 & 14.5 & $321-43$ & 0 & 1 & 1 & 0.5 \\
\hline $296-1$ & 2 & $24(12)$ & 26 & 13 & $498-3$ & 1 & 0 & 1 & 0.5 \\
\hline $332-17$ & 5 & $15(9)$ & 20 & 10 & F13-8* & 1 & 0 & 1 & 0.5 \\
\hline $\mathrm{F} 13-2^{*}$ & 7 & $13(4)$ & 20 & 10 & Various trees & 1 & 1 & 2 & 1 \\
\hline Mean & 10.9 & 18.5 & & & Mean & 0.7 & 0.4 & & \\
\hline
\end{tabular}


principal factor limiting fruit set, not nutrient status or physiological capacity of the trees.

Mean time from pollination to fruit maturity for the 77 fruits obtained from hand-pollination was 165 days (minimum 105, maximum 188), or approximately 5.5 months (Table 2). The correlation analysis between weight of fruit and days from pollination to their ripening was very low and not significant $(r=0.19 p=0.1)$. So, some trees mature their fruits faster than others. In both seasons, most fruits set by open pollination ripened between December and May, but the precise months in which ripe fruits were most abundant varied from year to year (Figure 4), reflecting variation in the timing of the preceding flowering seasons (Figure 2).

\section{Correlations between length and intensity of flowering, total flower production, and fruit production}

Table 3 shows the correlations between all pairs of these variables. Not surprisingly, the total number of flowers produced was correlated more strongly with the lengths of the periods of intense flowering (classes 2 and 3) than with the total length of the flowering season, which included the period of sparse (class 1) flowering. In both seasons, the number of

Table 2 - Number of days from pollination to fruit ripening of 77 fruits from 8 female cupuassu (Theobroma grandiflorum) trees. Averages followed by the same letter are not significantly different according to the $t$-test.

\begin{tabular}{lcc}
\hline Female tree & N & $\begin{array}{c}\text { Days from pollination to fruit ripening } \\
\text { (in average by female tree) }\end{array}$ \\
\hline $338-33$ & 2 & $137.5 \mathrm{a}$ \\
$339-42$ & 3 & $151.3 \mathrm{ab}$ \\
$332-17$ & 9 & $159.9 \mathrm{ab}$ \\
\hline F13-2 & 4 & $161.2 \mathrm{ab}$ \\
$229-25$ & 22 & $165.3 \mathrm{~b}$ \\
$492-60$ & 6 & $166.3 \mathrm{~b}$ \\
$283-56$ & 19 & $167.5 \mathrm{~b}$ \\
$296-1$ & 12 & $171.6 \mathrm{~b}$ \\
Mean & & 164.8 \\
\hline Minimum & & 105 \\
Maximum & & 188 \\
\hline
\end{tabular}

Table 3- Correlation coefficients between length of flowering, total number of flowers per tree and fruit production per tree (upper figure in each cell relates to the first season, lower figure to the second season; ${ }^{* *}$ significant at the $1 \%$ level).

\begin{tabular}{|c|c|c|c|c|c|}
\hline & \multicolumn{3}{|c|}{ Length of period in flowering class } & \multirow[t]{2}{*}{$\begin{array}{l}\text { Total length of } \\
\text { flowering period }\end{array}$} & \multirow[t]{2}{*}{$\begin{array}{l}\text { Total no. of flowers } \\
\text { per tree }\end{array}$} \\
\hline & $\begin{array}{c}1 \\
\text { (1-10 flowers) }\end{array}$ & $\begin{array}{c}2 \\
\text { (11-50 flowers) }\end{array}$ & $\begin{array}{c}3 \\
\text { (>50 flowers) }\end{array}$ & & \\
\hline $\begin{array}{l}\text { Length of period in flowering class } \\
2 \text { (11-50 flowers) }\end{array}$ & $\begin{array}{l}-0.14 \\
0.29 * \star\end{array}$ & & & & \\
\hline $\begin{array}{l}\text { Length of period in flowering class } \\
3 \text { (>50 flowers) }\end{array}$ & $\begin{array}{l}0.00 \\
0.21\end{array}$ & $\begin{array}{c}0.13 \\
0.76^{\star \star}\end{array}$ & & & \\
\hline Total length of flowering period & $\begin{array}{l}0.64^{* *} \\
0.87^{\star *}\end{array}$ & $\begin{array}{l}0.63^{\star *} \\
0.72^{\star \star}\end{array}$ & $\begin{array}{l}0.36^{\star *} \\
0.61^{\star *}\end{array}$ & & \\
\hline Total no. of flowers per tree & $\begin{array}{c}0.02 \\
0.41^{* *}\end{array}$ & $\begin{array}{l}0.76^{\star \star} \\
0.93^{\star *}\end{array}$ & $\begin{array}{l}0.73^{* *} \\
0.93^{* *}\end{array}$ & $\begin{array}{l}0.75^{\star \star} \\
0.80^{\star \star}\end{array}$ & \\
\hline Total no. of fruits per tree & $\begin{array}{l}-0.02 \\
0.43^{\star *}\end{array}$ & $\begin{array}{c}0.12 \\
0.60^{\star \star}\end{array}$ & $\begin{array}{l}0.50^{\star *} \\
0.73^{\star *}\end{array}$ & $\begin{array}{c}0.20 \\
0.66^{* *}\end{array}$ & $\begin{array}{l}0.40^{* *} \\
0.74^{* *}\end{array}$ \\
\hline
\end{tabular}




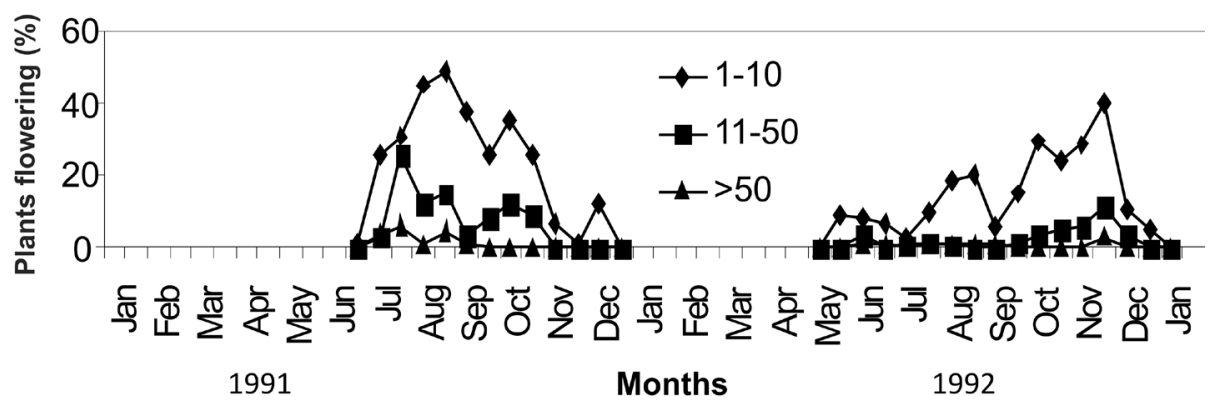

Figure 2 - Flowering period and level of flowering in the total population of cupuassu trees studied.

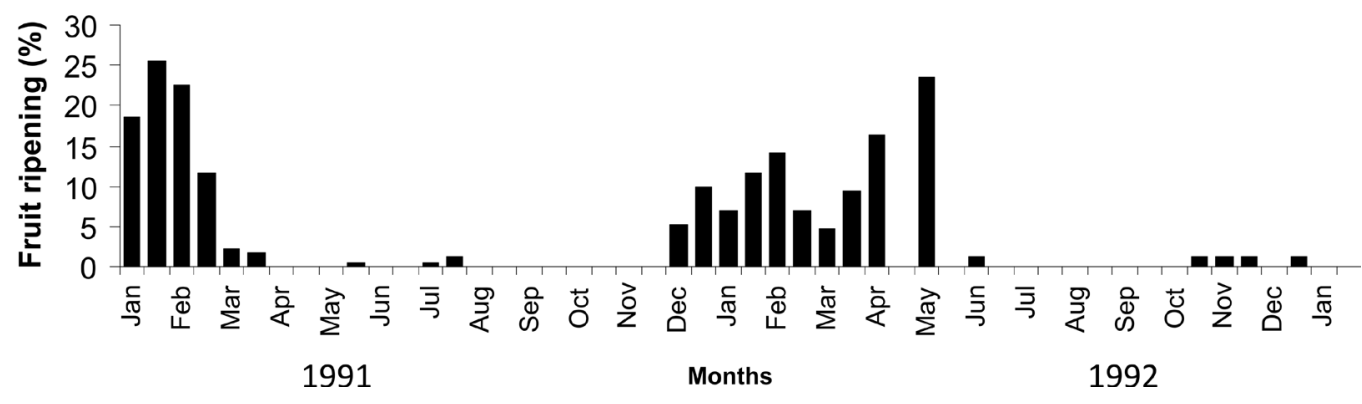

Figure 4 - Period of fruit ripening in cupuassu trees studied (based on 178 fruits in the first season and 162 fruits in the second season, all set by open pollination).

fruits produced per tree was significantly correlated with the total number of flowers per tree.

\section{DISCUSSION}

Fewer than $50 \%$ of the trees observed over two consecutive seasons produced any fruit. The mean number of fruits set per tree, from open pollination, was appreciably less (4.5-6.6) than the 12 fruits per tree obtainable from well-managed plantings of cupuassu (Calzavara et al. 1984; Falcão and Lleras 1983), and was comparable to the number of fruit set on wild trees (Calzavara et al. 1984). ). Trees which produced many flowers and fruits in one season produced only half or fewer of those in the following season (Figure $3 \mathrm{~b}$ ). Other trees yielded more evenly over consecutive seasons, but their yields were appreciably below those of the most productive trees.

The number of flowers produced per tree varied between different trees in the same season and between the same tree in different seasons in much the same way as fruit production. Fruit production per tree is likely to be determined partly by genotype, but also by external factors such as compatibility with near neighbors, amount of light received, and whether the tree is healthy or diseased. The heavily-cropping trees may tend to irregular bearing, as in many other fruit trees (Sedgley and Griffin 1989). Our data suggest that selection for yield and/or regular bearing may be effective in this relatively unimproved crop, but more carefully designed experiments, continued over a longer period, are necessary to demonstrate this conclusively.

Venturieri (1994) found that two-thirds of the flowers produced by cupuassu remain unpollinated. This, combined to the significant number of fruits produced by handpollination, suggests that the lack of effective pollination may explain, in part, the limited fruit set. Fruit production over the two seasons of our study was correlated slightly more strongly with the length of the period of peak flowering than with the total length of the flowering period or the total number of flowers per tree. This might suggest that trees bearing more flowers at a given time attract more pollinators, as Warren et al. (1995) found in Theobroma cacao. However, production of more flowers per day per individual is likely to result in more geitonogamous pollinations which, in a selfincompatible species like cupuassu (Venturieri 1994), would be ineffective.

Cupuassu flowers probably offer three different rewards to their insect visitors. Pollen is available as soon as the flowers 

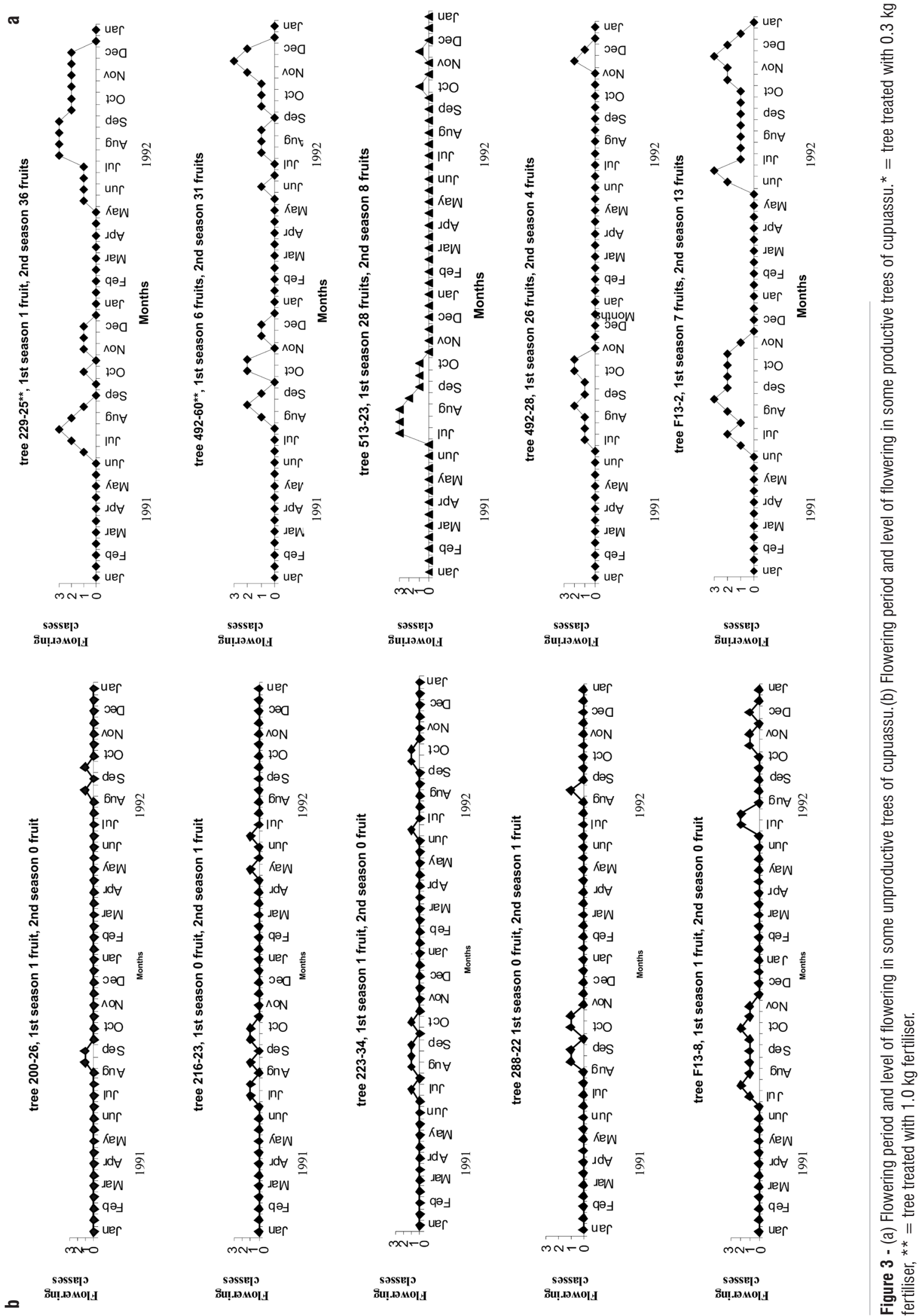
open, as is shelter in the petal pouches and/or within the ring of staminodes. The copious stigmatic exudate is another possible food reward. The flowers usually open mid to late afternoon and remain open for 24-36 hours, but the stigmatic exudate is produced most abundantly between 2:00 and 6:00 hours (Venturieri 1994). Cantharophily (beetle pollination) and Mellithophily (bee pollination) are accepted as possible pollination syndromes in cupuassu (Venturieri et al. 1997, Venturieri 1994). Regarding the two potential pollinators so far identified, the chrysomelid weevils may shelter in cupuassu flowers overnight, feed on pollen in the petal pouches, and then move on the following day when the flower wilts (Venturieri et al. 1997). It is not known whether these weevils would initially be attracted preferentially to trees with a larger display of flowers, or whether they would then tend to move from flower to flower on the same tree. Stingless bees, the other potential pollinators (Venturieri 1994) are more likely than weevils to be density-dependent foragers, and thus likely to bring about ineffective pollinations on selfincompatible trees displaying many flowers. However, these bees are strictly diurnal, and they are most active when the stigmas of cupuassu are not receptive (Venturieri 1994). Their importance as effective pollinators of cupuassu has still to be established. Venturieri (1994) found that the proportion of cupuassu flowers pollinated remained more or less constant throughout the flowering season. The correlation observed here between length of the period of peak flowering and fruit production may therefore indicate only that a rare event, such as fruit set in cupuassu, occurs more frequently as the number of opportunities for it to occur increases.

Our evidence indicates that increasing the levels of effective pollination in this population, and probably other populations of cupuassu should significantly increase the numbers of fruits produced. However, until more is known about the relative roles of the various potential pollinators, their life cycles and their behavior, no recommendations can be made about how to increase the proportion of flowers pollinated.

These preliminary and limited studies therefore suggest that low and irregular yields are the characteristic feature of cupuassu. It may nevertheless be possible to improve yield significantly in the short term by selection and in the longer term by breeding, and also by further investigation of the effects of factors such as provision or removal of shade, or addition of fertilizer. Further studies on the pollination of cupuassu may also be of practical as well as academic interest.

\section{ACKNOWLEDGMENTS}

This study was supported by a grant from the Margaret Mee Amazon Trust and formed part of the Ph.D. thesis conducted by G.A. Venturieri in the Department of Agricultural Botany, The University of Reading, U.K. We thank the Federal University of Pará (UFPa), the Executive Commission for Cocoa Planning (CEPLAC), and Paraense Museum Emílio Goeldi, for providing laboratory and field facilities necessary for this project. Our sincere thanks also go to Sr. Edilson de Freitas Leal, of the CEPLAC technical staff, for his assistance during the fieldwork and Barbara Pickersgill for suggestions given during the experiments and contributions in the text.

\section{LITERATURE CITED}

Calzavara, B.B.G.; Müller, C.H.; Kahwage, O.N.C. 1984. Tropical fruticulture: cupuassu. Cultivation, processing and fruit. EMBRAPA/CPATU, Belém, Brazil. 101p. (in Portuguese)

Clement, C.R.; Venturieri, G.A.. 1990. Bacuri and cupuassu. In: Nagy, S.; Shaw, P. E.; Wardowski, W. (Eds). Fruits of tropical and subtropical origin: composition, properties, uses. Florida Science Source, Lake Alfred, Florida. p. 178-192.

Faegri, K.; van der Pijl, L. 1979. The principles of pollination ecology, 3rd edition, Oxford: Pergamon Press, 244 pp.

Falcão, M.A.; Lleras, E. 1983. Phenological, ecological and productivity aspects of cupuassu (Theobroma grandiflorum (Willd. ex Spreng.) Schum.). Acta Amazonica, 13: 725-735. (in Portuguese, with abstract in English).

Free, J.B. 1993. Insect pollination of crops (2nd ed.). Academic Press, 684 p. London.

Garcia, J. de J.da S.; Morais, F.I. de O.; Almeida, L.C. de; Dias, J.C. 1985. Sistema de produção do cacaueiro na Amazônia Brasileira. CEPLAC/DEPEA, Belém, Brazil. 118 pp (in Portuguese).

Hoong-Yeet Y. 2007. Synchronous flowering of the rubber tree (Hevea brasiliensis) induced by high solar radiation intensity. New Phytologist, 175:283-289.

Moraes, V.H. de F.; Müller, C.H., Souza A.G.C. de; Antônio I.C. 1994. Native fruit species of economic potential from the Brazilian Amazon. Angewandte Botanik, 68: 47-52.

Parvais, L.P.; Reffye, Ph de; Lucas, P. 1977. Observations sur la polinisation libre chez Theobroma cacao: analyse mathématique des données et modélisation. Café Cacao Thé, 21: 253-62.

Rodrigues, A. de A.; Venturieri, G.A. 1997. Floral biology of "cupui" (Theobroma subincanum) - Sterculiaceae. Anais do I Encontro de Botânica Econômica de Espécies Nativas da América Latina; CATI - Campinas/SP/Brasil (21 e 22 de agôsto).

Sedgley, M.; Griffin, A.R. 1989. Sexual reproduction of tree crops. Academic Press London. 378 pp.

Silva, W.G. 1988. Cupuassu fat, as a substitute for cocoa butter. Ph.D. thesis, University of São Paulo, São Paulo, 124 (in Portuguese, with abstract in English).

Smith, N.J.H.; Williams, J.T.; Plucknett, D.L.; Talbot, J. 1992. Tropical forests and their crops. Ithaca: Cornell University Press, 568 pp.

Sokal, R.R.; Rohlf, F.J.. 1995. Biometry: the principles and practice of statistics in biological research. (3rd ed.). Freeman, New York, $887 \mathrm{pp}$. 


\section{ACTA}

Souza, M.S. de; Venturieri, G.A. 2010. Floral biology of cacauhy (Theobroma speciosum). Brazilian Archives of Biology and Technology, (in press).

Souza, S.P. de; Venturieri, G.A. 1998. Floral phenology of cacaucabeça-de-urubu (Theobroma obovatum). First Report: CNPq/ Programa de Trópico Úmido - PUT/Proc. n. 63.00.13/95. Belém, PA. 105 pp.

Stephenson, A.G. 1981. Flower and fruit abortion: proximate causes and ultimate functions. Annual Review of Ecology and Systematics, 12: 253-279.

Venturieri, G.A. 1993. Cupuassu: the species, its cultivation, uses and processing. Belém: Clube do Cupu, 108pp (in Portuguese).

Venturieri, G.A. 1994. Floral biology of cupuassu (Theobroma grandiflorum (Willdenow ex Sprengel) Schumann). Ph.D. Thesis, University of Reading, Reading UK, 211 pp.
Venturieri, G.A.; Ribeiro Filho, A.A. 1995. Hand pollination of cupuassu trees (Theobroma grandiflorum (Willdenow ex Sprengel) Schumann). Acta Amazonica, 25: 181-192 (in Portuguese, with abstract in English).

Venturieri, G.C.; Maués, M.M.; Miyanaga, R. 1997. Polinização do cupuaçuzeiro (Theobroma grandiflorum-Sterculiaceae): um caso de cantarofilia em uma fruteira amazônica. International Symposium of Cupuassu and Black-Pepper. Documentos Embrapa Amazônia Oriental/JICA vol. 89, p. 341-350, Belém, PA.

Warren, J.M.; Kalai, Misir, S. 1995. An unnatural breeding system polymorphism in cacao (Theobroma cacao, Sterculiaceae) in Trinidad. American Journal of Botany, 82: 1126-1130.

Recebido em 05/04/2010

Aceito em 07/07/2010 
